\title{
Technical Note: Use of remote sensing for landslide studies in Europe
}

\author{
V. Tofani, S. Segoni, A. Agostini, F. Catani, and N. Casagli \\ Department of Earth Sciences, University of Firenze, Florence, Italy \\ Correspondence to: V. Tofani (veronica.tofani@unifi.it) \\ Received: 17 April 2012 - Published in Nat. Hazards Earth Syst. Sci. Discuss.: - \\ Revised: 10 December 2012 - Accepted: 7 January 2013 - Published: 8 February 2013
}

\begin{abstract}
Within the framework of FP7, an EU-funded SafeLand project, a questionnaire was prepared to collect information about the use of remote sensing for landslide study and to evaluate its actual application in landslide detection, mapping and monitoring. The questionnaire was designed using a Google form and was disseminated among endusers and researchers involved in landslide studies in Europe. In total, 49 answers from 17 different European countries were collected. The outcomes showed that landslide detection and mapping is mainly performed with aerial photos, often associated with optical and radar imagery. Concerning landslide monitoring, satellite radars prevail over the other types of data. Remote sensing is mainly used for detection/mapping and monitoring of slides, flows and lateral spreads with a preferably large scale of analysis $(1: 5000-$ $1: 25000)$. All the compilers integrate remote sensing data with other thematic data, mainly geological maps, landslide inventory maps and DTMs and derived maps. According to the research and working experience of the compilers, remote sensing is generally considered to have a medium effectiveness/reliability for landslide studies.

The results of the questionnaire can contribute to an overall sketch of the use of remote sensing in current landslide studies and show that remote sensing can be considered a powerful and well-established instrument for landslide mapping, monitoring and hazard analysis.
\end{abstract}

\section{Introduction}

Landslides are one of the most serious geological hazards, which threaten and influence the socio-economic conditions of many countries in Europe and worldwide, causing damages and casualties (Schuster, 1996; Schuster and Highland, 2001; Petley et al., 2005; Petley, 2012).

The observation of the Earth from space has found many uses in the natural sciences, but it is only in the last decades that technological advances have also extended to landslides (Singhroy, 1995; Mantovani et al., 1996; Massonnet and Feigl, 1998; Ferretti et al., 2001; Canuti et al., 2004; Hong et al., 2007; van Westen et al., 2008; Martha et al., 2010; Ferretti et al., 2011).

Today, rapid advances are making Earth observation (EO) techniques more effective for landslide detection, mapping, monitoring and hazard analysis. Applications are originating from nearly all types of sensors available today. For instance, rapid developments in this field are fostered by the very high spatial resolution obtained by optical systems (currently in the order of tens of centimeters) and by the launching of SAR (Synthetic Aperture Radar) sensors, purposely built for interferometric applications with revisit times of a few days, such as TerraSAR X and COSMO-SkyMed. Moreover, in the last years satellites have provided accurate measurements of precipitation such as the Tropical Rainfall Measuring Mission (TRMM), which was launched in 1997. Remote rainfall measurements can be used to predict rainfall-induced landslides in the framework of landslide hazard analysis (Adler et al., 2000; Hong et al., 2006; Segoni et al., 2009; Baum and Godt, 2010; Rossi et al., 2013).

Landslide detection and mapping benefit from both optical and radar imagery. In the field of optical imagery a new generation of high-resolution satellites, such as World-View, Geo-eye, and the Pleiades constellation present resolutions ranging from $0.5 \mathrm{~m}$ to $2 \mathrm{~m}$ and offer a very powerful tool for a quick reproduction of regional inventory maps (up to a scale of $1: 2000$ ). Their cost/benefit ratio is relatively low, 
considering that these satellites have a global coverage and that the acquisition "on demand" makes the images readily available (Casagli et al., 2005; Lu et al., 2011).

The analysis of optical imagery for landslide mapping can be performed through (i) visual interpretation of single and stereoscopic images (Soeters and van Westen, 1996); (ii) image classification with semi-automated pixel-based methods (Borghuis et al., 2007; Marcelino et al., 2009); (iii) image classification with semi-automated object-oriented methods (Martha et al., 2010; Lu et al., 2011; Stumpf and Kerle, 2011); (iv) change detection techniques (Nichol and Wong, 2005; Weirich and Blesius, 2007; Tsai et al., 2010); and (v) correlation of optical images (Delacourt et al., 2007; Leprince et al., 2007; Debella-Gilo and Kääb, 2011).

Optical satellite images are also useful for indirect mapping methods, i.e. to identify the distribution of slope instability factors such as topography (Anders et al., 2009), geology and lithology (Sarkar and Kanungo, 2004; Grebby et al., 2011) and land use (Cheng et al., 2004; Casagli et al., 2005; Catani et al., 2005; Kirschbaum et al., 2009).

One of the most promising research fields related to the measurement of ground movements derives from the development of satellite radar interferometry. In particular, the application of multi interferograms SAR Interferometry (ADInSAR) techniques to the study of slow-moving landslides (velocity $<13 \mathrm{~m} \mathrm{month}^{-1}$ according to Cruden and Varnes, 1996) is a relatively new and challenging topic. A-DInSAR techniques are PSInSAR ${ }^{\mathrm{TM}}$ (Ferretti et al., 2000, 2001; Colesanti et al., 2003), the SqeeSAR (Ferretti et al., 2011), the Stanford Method for Persistent Scatterers (StaMPS) (Hooper et al., 2004, 2007), the Interferometric Point Target Analysis (IPTA) (Werner et al., 2003; Strozzi et al., 2006), Coherence Pixel Technique (CPT) (Mora et al., 2003; Lanari et al., 2004), Small Baseline Subset (SBAS) (Berardino et al., 2003; Casu et al., 2006) and Stable Point Network (SPN) (Crosetto et al., 2008; Herrera et al., 2011). Scientific literature reports some successful case studies dealing with the detection and the mapping of landslide phenomena, as discussed in Hilley et al. (2004); Catani et al. (2005); Strozzi et al. (2005); Colesanti and Wasowski (2006); Canuti et al. (2007); Wasowski et al. (2007); Casagli et al. (2009); Cascini et al. (2009); Lu et al. (2012); Righini et al. (2012).

The monitoring of landslides by means of optical imagery can be performed by correlating optical data. This methodology has been used to measure displacements not only for landslides (Delacourt et al., 2004, 2007; Casson et al., 2005) but also for earthquakes (Van Puymbroeck et al., 2000) and for glacier flows (Kääb, 2002; Berthier et al., 2005). The capability of DIC (Digital Image Correlation) to monitor landslide surfaces over multiple time steps has been demonstrated with aerial photographs (Casson et al., 2005) and Terrestrial Optical Photogrammetry (Sturzenegger and Stead, 2009; Travelletti et al., 2012). Only a few studies have reported the usefulness of satellite images in this field (Delacourt et al., 2007, 2009; Leprince et al., 2008) and exhaustive research addressing to the analysis of longer available very high resolution (VHR) satellite time series is still missing.

Both differential SAR interferometry (DInSAR) and multi-interferograms SAR interferometry (A-DInSAR) can be used for landslide monitoring: quantitative information on landslide activity can be acquired in the case of extremely slow movements (velocity $<16 \mathrm{~mm} \mathrm{yr}^{-1}$ according to Cruden and Varnes, 1996), affecting large areas with sparse vegetation (Fruneau et al., 1996; Rott and Siegel, 1999; Kimura and Yamaguchi, 2000; Rizzo and Tesauro, 2000).

There is an extensive bibliography of works on the use of DInSAR and PS-InSAR for landslide monitoring (Berardino et al., 2003; Singhroy and Molch, 2004; Strozzi et al., 2005; Meisina et al., 2007; Fornaro et al., 2009; Prati et al., 2010). In many cases the A-DInSAR data have been integrated with in situ monitoring instrumentation (Peyret et al., 2008; Pancioli et al., 2008; Tofani et al., 2010; Strozzi et al., 2010). The joint use of satellite and ground-based data facilitates the geological interpretation of a landslide and allows a better understanding of landslide geometry and kinematics.

Despite the extensive bibliography available concerning remote sensing techniques and their application to landslide mapping and monitoring, international literature still lacks a complete framework explaining how and how much these techniques are operatively used nowadays in Europe by universities, research institutes, public agencies and private companies.

With this objective the Department of Earth Sciences of the University of Firenze prepared a questionnaire to investigate the role of remote sensing for landslide study. This questionnaire has been prepared in the framework of the FP7-funded SafeLand project (2009-2012, Grant Agreement No. 226479).

The SafeLand project, among many other issues, was addressed to the development of monitoring technology, especially early warning systems and remote sensing techniques. The research focuses on the detection, monitoring and efficient mapping of landslides, with scales ranging from regional to slope. The SafeLand project was involved in the development of new procedures, techniques, hardware and software for landslide study and the evaluation of existing ones. In order to make an evaluation of the existing remote sensing techniques, the aim of the questionnaire was to collect information about the use of remote sensing in Europe for landslide study and to estimate its actual application in landslide detection, mapping and monitoring. Some preliminary results on the evaluation have been presented in Tofani et al. (2011). 


\section{Material and methods}

The questionnaire was designed using a Google form (https://spreadsheets.google.com/ spreadsheet/viewform?hl=en_US\&formkey= dG5qUzFoRHp3WTBhbmh2cU15UWVYdUE6MA\# gid=0) and was distributed in Europe amongst the community involved in landslide study. We contacted researchers, technicians, and end-users, covering as much of Europe as possible using two main approaches: mailing lists of participants to landslide-related thematic sessions of international congresses, and contacts coming from different partnerships and collaborations in some important FP7 and FP6-funded projects on landslides.

The questionnaire was arranged to be as comprehensible and user-friendly as possible and the answers were automatically collected in a Google spreadsheet. Only a few open questions were included and the majority of the questions were checkboxes, in which more than one answer could be picked. To guide the compiler throughout the questionnaire, an introductory help text was also provided. Since our main objective was to picture how and how much remote sensing is currently used in landslide studies, whoever filled the questionnaire was asked to compile it according to his/her actual use rather than to the one he/she would have theoretically used.

The questionnaire was structured into three different sections: the first one related to the general information of the questionnaire compiler (institution, location, country, contact person, e-mail), the second devoted to landslide detection and mapping (11 questions) and the third one addressed to landslide monitoring (13 questions). An overview of the questions is reported in Table 1. At the end of each section some space was left for additional comments.

The subdivision in sections stresses the approach followed in this work: detection/mapping studies and monitoring studies are considered as separate and if not explicitly stated otherwise, the percentages reported in this work are not calculated on the total number of responses, but they are calculated separately on the number of compilers that used remote sensing for detection/mapping and on those who used it for monitoring purposes.

On the whole, 49 answers were collected from 17 different European countries (Fig. 1). Even if at a first glance the answers could seem biased towards some countries (such as Italy, 17 responses, and Spain, 6 responses), the spatial distribution of the answers portrayed in Fig. 1 is consistent with the distribution of landslides in Europe. In particular Van Den Eeckhaut and Hervas (2012) report that about the $75 \%$ of the European landslides registered in national and/or regional databases are located in Italy, where the official Italian IFFI Inventory reports over 480000 landslides in the whole country (Trigila et al., 2010). Furthermore the spatial distribution of the answers is compatible with the significance of landslides impact on society (Guzzetti, 2000; Canuti et al., 2004;

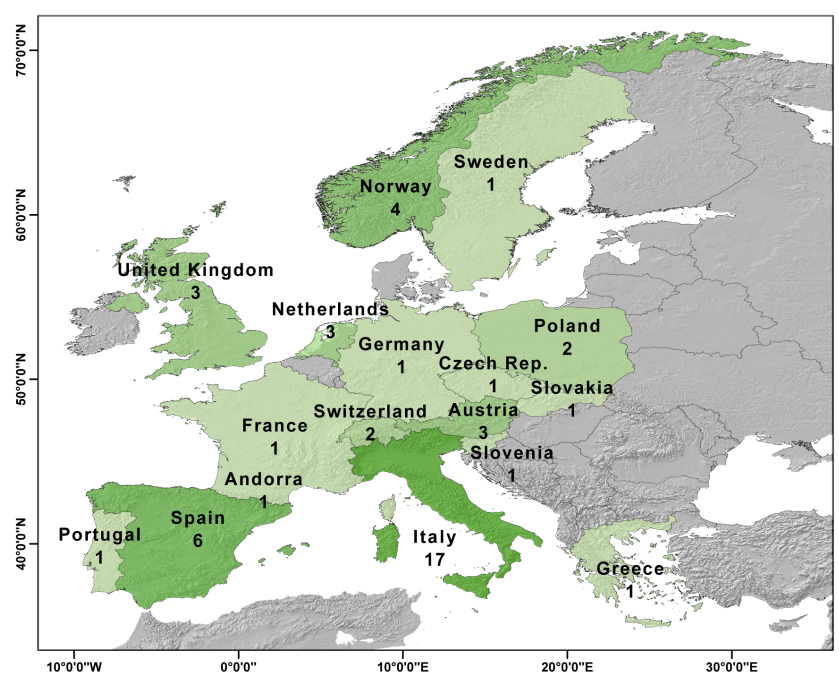

Fig. 1. Countries of origin of the answers to the questionnaire.

Guzzetti et al., 2005; Gibson et al., 2012) and the estimated landslide susceptibility in the various countries (Günther et al., 2012; Van Den Eeckhaut et al., 2012). In addition, a similar spatial distribution of the responses was obtained by Dikau et al. (1996) in a questionnaire about GIS and database use in landslide studies.

The answers to our questionnaire came from different kinds of institutions: $39 \%$ of the compilers worked at universities, $24 \%$ at research institutes, $30 \%$ at public agencies (Geological Surveys, River Basin Authorities, etc.) and $7 \%$ at private companies. Partners and end-users of the SafeLand project gave a substantial contribution to the survey, providing $25 \%$ of the answers.

\section{Results}

The questionnaire outcomes show that in Europe, remote sensing is more frequently used for detection/mapping of landslides than for monitoring purposes. The $83 \%$ of the compilers use remote sensing for both detection/mapping and monitoring, while $17 \%$ use it only for detection and mapping purposes and no one uses it exclusively for monitoring.

The compilers of the questionnaire reported using a variety of different remotely sensed data (Fig. 2). The most common are aerial photos, satellite radar, satellite optical and meteorological sensors, with percentages that considerably differ when the same data are used for detection/mapping or for monitoring (Fig. 2). A more restricted number of answers was related to other three kinds of data that are used for both detection/mapping and monitoring (Fig. 2): airborne and terrestrial LIDAR, airborne geophysics, and GB-InSAR. A small percentage of answers was related to the data used only for monitoring purposes (infrasound, ultrasonic). 
Table 1. Questionnaire overview.

\begin{tabular}{|c|c|c|c|c|c|}
\hline \multirow{13}{*}{ 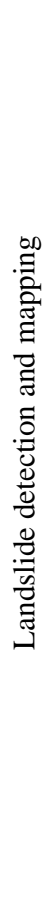 } & 1 & $\begin{array}{l}\text { Remotely sensed data used for landslide detection } \\
\text { and mapping }\end{array}$ & & 1 & Remotely sensed data used for landslide monitoring \\
\hline & 2 & $\begin{array}{l}\text { Landslide parameters identified through remote } \\
\text { sensing }\end{array}$ & & 2 & Parameters monitored through remote sensing \\
\hline & 3 & Optical spectral ranges & $\stackrel{\infty}{\Xi}$ & 3 & Optical spectral ranges \\
\hline & 4 & $\begin{array}{l}\text { Optical techniques for landslide detection and map- } \\
\text { ping }\end{array}$ & हี & 4 & Optical techniques for landslide monitoring \\
\hline & 5 & Radar spectral bands & $\gtrsim$ & 5 & Radar spectral bands \\
\hline & 6 & $\begin{array}{l}\text { Radar techniques for landslide detection and map- } \\
\text { ping }\end{array}$ & $\overbrace{\overparen{\Xi}}^{\varpi}$ & 6 & Radar techniques for landslide monitoring \\
\hline & 7 & Type of landslide detectable through remote sensing & $\stackrel{00}{\Xi}$ & 7 & $\begin{array}{l}\text { Type of landslide monitored through remote sens- } \\
\text { ing }\end{array}$ \\
\hline & 8 & $\begin{array}{l}\text { Scale of analysis for landslide detection and map- } \\
\text { ping through remote sensing }\end{array}$ & 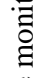 & 8 & $\begin{array}{l}\text { Scale of analysis for landslide monitoring through } \\
\text { remote sensing }\end{array}$ \\
\hline & 9 & Integration with other thematic data & $\frac{\pi}{\pi}$ & 9 & $\begin{array}{l}\text { Landslide velocities monitored through remote } \\
\text { sensing }\end{array}$ \\
\hline & 10 & $\begin{array}{l}\text { Landslide predisposing factors detectable through } \\
\text { remote sensing }\end{array}$ & త్ & 10 & $\begin{array}{l}\text { Integration of remotely sensed data with ground- } \\
\text { based techniques }\end{array}$ \\
\hline & & & & 11 & Integration with other thematic data \\
\hline & 11 & $\begin{array}{l}\text { Effectiveness/reliability of remotely sensed data for } \\
\text { landslide detection and mapping }\end{array}$ & & 12 & $\begin{array}{l}\text { Duration of landslide monitoring by means of } \\
\text { remote sensing data and main reasons for the } \\
\text { interruption of monitoring, if any }\end{array}$ \\
\hline & & & & 13 & $\begin{array}{l}\text { Effectiveness/reliability of remotely sensed data for } \\
\text { landslide monitoring }\end{array}$ \\
\hline
\end{tabular}

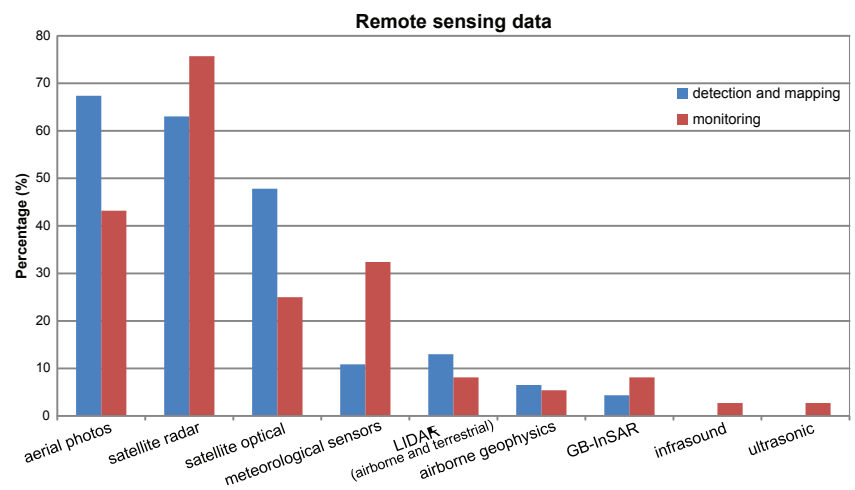

Fig. 2. Remotely sensed data in landslide study.

Of course, all these remotely sensed data do not exclude each other; on the contrary, most of the compilers used a combination of two or more different data. For detection and mapping of landslides, about $75 \%$ of the compilers used more than one remote sensing type of data, while the percentage decreases to $69 \%$ when remote sensing is used for monitoring purposes. In general the use of satellite optical and satellite radar is associated with the use of aerial photos and the combinations of these three techniques are the most reported.

In the field of optical data imagery, the most used techniques are visual interpretation $(87 \%$ for detection and mapping, $79 \%$ for monitoring), photogrammetry ( $47 \%$ and
$50 \%$ ) and change detection (37\% and 46\%) (Fig. 3a). Almost each technique reports very similar percentages for detection/mapping and for monitoring, except for image processing, which is more employed in monitoring $(45 \%)$ than in detection/mapping (29\%), and for the use of spectral indices, which conversely are more employed in detection/mapping (18\%) than in monitoring (4\%) applications.

Still considering optical data imagery for both detection/mapping and monitoring, the spectral ranges most commonly used are the visible (77\% and $72 \%$ of answers, respectively) and the multispectral $(60 \%$ and $56 \%)$. The use of NIR (Near Infrared) is also quite common as it is employed by $40 \%$ of the compilers for detection and mapping purposes.

Concerning radar data imagery, the $\mathrm{C}$ band is the most used ( $84 \%$ for detection/mapping and $85 \%$ for monitoring) since the majority of the satellite missions providing data for the DInSAR in the last decade were operating at this band (Prati et al., 2010). The most used technique is A-DInSAR (PS-InSAR, IPTA, SBAS, etc) with a percentage of $76 \%$ for detection/mapping and $73 \%$ for monitoring (Fig. 3b). A relevant number of compilers makes use of D-InSAR ( $58 \%$ and $43 \%$ ), while SAR and GB-InSAR are less widespread (Fig. 3b).

In landslide studies, the remotely sensed data are usually analyzed and visualized in conjunction with other thematic data (Fig. 3c). Concerning detection and mapping, all the users agreed on the necessity to integrate remotely 


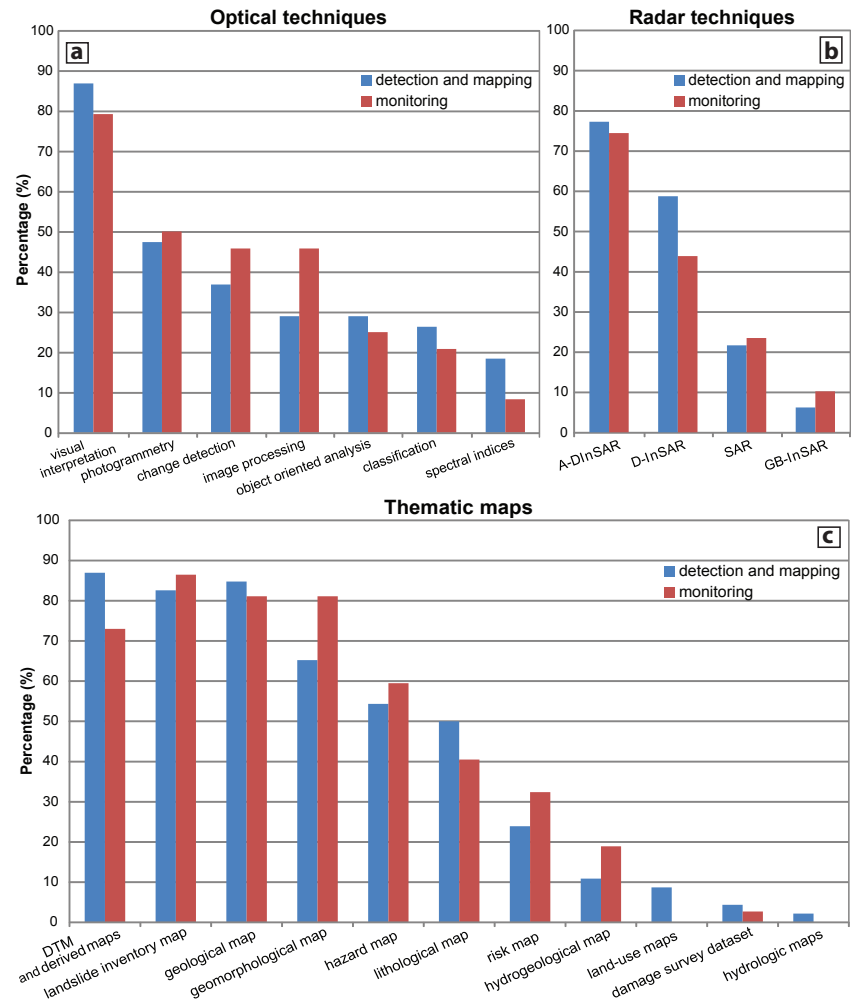

Fig. 3. (a) Optical techniques employed in landslide study. (b) Radar techniques employed in landslide study. (c) Integration of remote sensing data with other thematic data for landslide study.

sensed data with other thematic data such as DTMs and derived maps $(87 \%)$, geological maps $(85 \%)$, or preexisting landslide inventory maps $(83 \%)$. The integration with other thematic data is common for the monitoring of landslides as well, especially with landslide inventory maps (87\%), geomorphological $(81 \%)$ and geological maps $(81 \%)$, and DTMs and derived maps (73\%) (Fig. 3c).

Remote sensing is a useful tool to also detect landslide predisposing factors, especially over large areas, and the $75 \%$ of the compilers do it on a regular basis. Among them, $89 \%$ have indicated DTM and derived parameters (e.g. slope gradient), $58 \%$ lands use, $36 \%$ hydrology and $22 \%$ lithology.

In landslides monitoring, remote sensing is commonly integrated with one or more ground-based monitoring techniques. Among the latter, the most used are GPS (58\%), LIDAR TLS (48\%), inclinometers (48\%), GB-InSAR (48\%) and total stations $(33 \%)$, followed by wire extensometers $(27 \%)$, automatic inclinometers $(20 \%)$ and optical fibers (9\%), while crack-meters, geophysical methods and rod extensometers are less used ( $<2 \%$ of the answers).

A crucial point in landslide studies is the identification of appropriate technologies for each specific scientific problem. Table 2 lists how remote sensing is employed according to different features of the landslides. Following the classifications proposed by Cruden and Varnes (1996) and by Fell et al. (2008), the given answers highlight that the use of remote sensing is well established for slides (both rotational and translational) and extremely low and very slow movements, especially in large scale applications. However, recent advances in remote sensing technology have brought the possibility of successful applications also for landslides of every other typology and velocity (Table 2). Similarly, remote sensing is employed to investigate a large variety of landslide parameters: some of them are very well established (e.g. geometry, activity, velocity, displacement and deformation), but in a few cases new emerging remote sensing techniques (such as airborne geophysics) are currently applied to investigate also other parameters (e.g. detection of peculiar morphological and geological structures or monitoring of volume changes) (Table 2).

According to the answers we gathered, the monitoring duration is variable from a few weeks to some decades. This wide range is closely related to the used technique: a few days or weeks for GB-InSAR, 1-2 yr with TLS, decades for optical photos and satellite images surveys (depending on the archives). Still, within the same techniques, some outlier values of durations are reported, especially concerning recent developments achieved by research institutes (e.g. discontinuous use of GB-InSAR covering period of some months, Noferini et al., 2005 and Luzi et al., 2010). Obviously, the monitoring duration is influenced also by the landslide type, mechanism and velocity. The main reported reasons for the permanent interruption of monitoring are due to budget and fund problems, while temporary interruptions are mainly caused by meteorological conditions (i.e. a snow cover for both ground-based and airborne techniques) and hardware malfunctioning. Moreover, monitoring may be stopped after several years of inactivity of the landslide.

\section{Discussion and conclusions}

The present study contributes to draw a sketch of the use of remote sensing in current landslide studies in Europe and shows that remote sensing can be considered a powerful instrument for landslides mapping, monitoring and hazard analysis. This study was mainly based on the evaluation of the answers to a questionnaire designed using a Google form with multiple choices questions. The answers came from 17 countries all over Europe.

The spatial distribution of the answers is consistent with the distribution of landslides in Europe, the significance of landslides impact on society and the estimated landslide susceptibility in the various countries.

The results of the questionnaire show in general that landslide detection and mapping are mainly performed with aerial photos, often associated to optical and radar imagery. Concerning landslide monitoring, the satellite radar prevails on the other types of data, followed by aerial photos and meteorological sensors. A more in depth analysis reveals that 
Table 2. Percentage of remote sensing employment according to different features of the case of study (landslide typology, velocity, parameters to be investigated and scale of analysis).

\begin{tabular}{|c|c|c|c|}
\hline & & $\begin{array}{r}\text { Detection \& } \\
\text { mapping }\end{array}$ & Monitoring \\
\hline \multirow{5}{*}{ Landslide typology } & Slides & $100 \%$ & $100 \%$ \\
\hline & Flows & $70 \%$ & $58 \%$ \\
\hline & Spreads & $32 \%$ & $26 \%$ \\
\hline & Falls & $26 \%$ & $21 \%$ \\
\hline & Topples & $11 \%$ & $8 \%$ \\
\hline \multirow{5}{*}{ Landslide velocity } & Extremely slow & - & $72 \%$ \\
\hline & Very slow & - & $75 \%$ \\
\hline & Slow & - & $42 \%$ \\
\hline & Moderate & - & $14 \%$ \\
\hline & $>$ Rapid & - & $10 \%$ \\
\hline \multirow{12}{*}{$\begin{array}{l}\text { Landslides parameters } \\
\text { detectable by remote } \\
\text { sensing }\end{array}$} & Geometry & $91 \%$ & - \\
\hline & State of activity & $67 \%$ & - \\
\hline & Velocity & $59 \%$ & $60 \%$ \\
\hline & Typology & $54 \%$ & - \\
\hline & Volume & $28 \%$ & $3 \%$ \\
\hline & Soil moisture & $2 \%$ & - \\
\hline & Morphology & $2 \%$ & - \\
\hline & Structure & $2 \%$ & - \\
\hline & Displacement & - & $100 \%$ \\
\hline & Deformation & - & $66 \%$ \\
\hline & Rainfall & - & $34 \%$ \\
\hline & Other triggers & - & $11 \%$ \\
\hline \multirow{4}{*}{ Scale of analysis } & Detailed $(>1: 5 \mathrm{k})$ & $50 \%$ & $62 \%$ \\
\hline & Large $(1: 5 \mathrm{k}-25 \mathrm{k})$ & $78 \%$ & $69 \%$ \\
\hline & $\operatorname{Medium}(1: 25 \mathrm{k}-100 \mathrm{k})$ & $53 \%$ & $44 \%$ \\
\hline & Small $(<1: 100 \mathrm{k})$ & $20 \%$ & $18 \%$ \\
\hline
\end{tabular}

those techniques are similarly ranked, also when the answers are subsampled according to the different typology of institutions (i.e. universities, research institutes, and end users like public agencies and private companies). Since a clear gap between research institutes and end users is not noticeable, we may infer that in landslide remote sensing, the research is advancing at the same pace as its day-to-day application.

One of the features that may influence the end-users' decision in selecting the technique to be used in the landslide monitoring or detection/mapping is the costs (Stumpf et al., 2012). Obviously, other criteria being equal, the cheapest technology is commonly preferred. The costs of the raw input data are highly variable. For instance, airborne LiDAR has a high cost, since a scanning with a 0.5 points $\mathrm{m}^{-2}$ density over large areas costs $100-300 € \mathrm{~km}^{-2}$, which may increase when higher density point clouds are needed. Conversely, in some circumstances, remotely sensed data may be even got for free: many users reported making use of aerial photographs because they have free access to large historical data, others claim to have free access to satellite radar data provided for free by national institutions. This can partially explain why such large use is made of aerial photographs and SAR interferometry, as reported by the survey. Another possible relevant source of costs are the additional costs for processing, software acquisition and instruments installation, which may vary significantly even between different methods of the same technology. The processing costs for A-DinSAR technology, for example, can range from $2000 € / 100 \mathrm{~km}^{2}$ (retrospective analysis for up to $7 \mathrm{yr}$ over large areas) to $35000 € / 100 \mathrm{~km}^{2}$ (retrospective analysis for up to $7 \mathrm{yr}$ over small areas) (Stumpf et al., 2012). Anyhow, some spaceborne technologies have reduced processing costs: for example ASTER satellites data can be processed with free software.

Both detection/mapping and monitoring of landslides are applied to slides, flows and lateral spreads, and rarely other types of movements (falls, topples) are mentioned. The scale of analysis is usually the large scale $(1: 5000-1: 25000)$.

All the compilers integrate remote sensing data with other thematic data, mainly geological maps, DTMs and derived maps and landslide inventory maps.

On the basis of their research and working experience, the compilers evaluated the effectiveness and reliability of remote sensing for landslide detection and mapping and for 


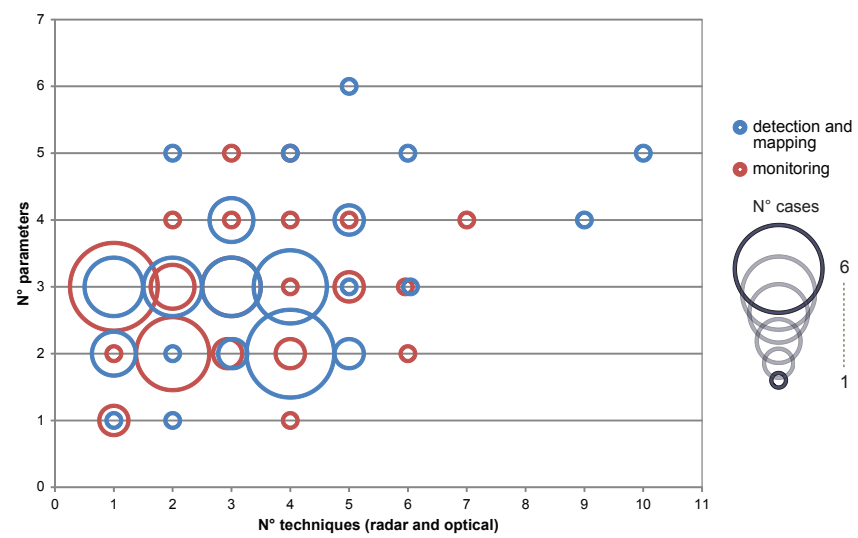

Fig. 4. Number of employed remote sensing techniques (radar and optical) versus number of observed parameters.

landslide monitoring. In general, remote sensing is considered to have a medium effectiveness/reliability for landslide studies (the percentage is around $50 \%$ for both monitoring and detection/mapping). A relevant percentage of users consider remote sensing a highly reliable/effective instrument for detection and mapping (45\%) and monitoring (36\%). Only a few compilers reported a negative opinion $(6 \%$ for detection and mapping, $15 \%$ for monitoring). In addition to subjective assessments, the estimated degree of effectiveness/reliability also depends on how remote sensing is used. For instance, we observed that an increase in the number of remote sensing data type (aerial photos, satellite optical, satellite radar etc.) used by the compilers, corresponds to a growth of the degree of effectiveness/reliability. Concerning landslide monitoring, the high degree of effectiveness/reliability increases according to the number of used data types.

In general the number of parameters detectable through remote sensing (both optical and radar) is linked to the number of techniques employed. Figure 4 highlights that the increase in the number of measured parameters is related to an increase in the number of the techniques used, both for monitoring and for detection/mapping. Obviously, this behavior would be clearer if the number of answers was higher, especially because anomalous answers (as the points representing 4 techniques used to monitor a single parameter) could more clearly appear as outliers in a larger sample. Ten answers reported the possibility of detecting three parameters by means of a single technique: all of them reported using radar technologies and this could be considered as an indicator of a better efficiency of radar with respect to optical techniques.

In conclusion, considering the effectiveness, reliability and diffusion of the various techniques, landslide detection/mapping and monitoring in Europe mainly profit from the use of optical and radar imagery. In particular, a combination of both is commonly used to obtain the best results. Moreover in the last years the research is moving toward the set-up of semiautomatic procedures for the rapid mapping of landslides over large areas, both for radar and optical imagery (Lu et al., 2011, 2012; Stumpf and Kerle, 2011).

Concerning landslide monitoring, the results of the questionnaire stressed that the best results can be obtained combining remote sensing with ground based networks data and in field observations. This integration can allow defining the deformation patterns of a landslide, its relationship with the triggering conditions and can also provide a sound support for landslide modeling.

Apart from optical and radar imagery, other techniques are less widespread and some of them are not so well established (e.g. airborne geophysics), notwithstanding their performances are increasing at a fast rate as scientific and technological improvements are accomplished.

The application of airborne and spaceborne remote sensing in landslide analysis is currently providing effective results in Europe. Aerial and satellite remote sensing are so far the most widespread, but a series of different supports are emerging (e.g. drones, helicopters and boats).

The answers to the questionnaire show that remote sensing techniques are affected by some limitations and critical points, which have to be addressed by the researchers and technicians to increase the effectiveness of the landslide detection, mapping and monitoring. The main challenge in this regard is the improvement of the spatial resolution and the shortening of the revisiting time. The Cosmo-SkyMED (in $\mathrm{X}$ band) constellation, which was launched in 2007, has a short revisiting time ( $12 \mathrm{~h}$ in the better case), such as ALOS mission (in L band) launched in 2006. Nevertheless, time is needed before these missions will provide achievements that could be effectively employed in multi-temporal processing. Improvements are also expected in optical imagery from the development of the Pleiades program by the CNES: it is tailored on civil security applications and it consists of two small satellites (the first of which is currently operating and has been since the end of 2011, while the second one is scheduled for the end of 2012) with a spatial resolution at nadir of $0.7 \mathrm{~m}$ with a daily access all over the world and a stereoscopic acquisition capacity. The full operational use of all the satellite missions and the new ones already on board is outstanding to retrieve data and information tailored to the user's requirements in terms of short revisiting time, high spatial resolution and cost/benefit ratio. Lastly, enhancements and optimizations of new software and algorithms are expected in order to reduce computational time and to increase automation and robustness to avoid as much subjective judgment as possible.

In conclusion, remote sensing can be considered a powerful and well-established instrument for landslide mapping, monitoring and hazard analysis and a wide range of available techniques and source data can be approached depending on the size and velocity of the investigated phenomena. This work can help in recognizing the present state of actual 
EO applications to landslide studies and in addressing the weakest points in future research.

Acknowledgements. The work described in this paper was supported by the project SafeLand "Living with landslide risk in Europe: Assessment, effects of global change, and risk management strategies" under Grant Agreement No. 226479 in the 7th Framework Programme of the European Commission. This support is gratefully acknowledged.

The authors would also like to thank all the questionnaire's compilers for their fundamental contribution and Patrizia Musina for the English version of the text.

Edited by: A. Günther

Reviewed by: four anonymous referees

\section{References}

Adler, R. F., Huffman, G. J., Bolvin, D. T., Curtis, S., and Nelkin, E.J.: Tropical rainfall distributions determined using TRMM combined with other satellite and rain gauge information, J. Appl. Meteor., 39, 2007-2223, 2000.

Anders, N. S., Seijmonsbergen, A. C., and Bouten, W.: Multi-scale and object-oriented image analysis of high-resolution LiDAR data for geomorphological mapping in Alpine mountains, in: Geomophometry, Zurich, Switzerland, 2009.

Baum, R. L. and Godt, J. W.: Early warning of rainfall-induced shallow landslides and debris flows in the USA, Landslides, 7, 259272, 2010

Berardino, P., Costantini, M., Franceschetti, G., Iodice, A., Petranera, L., and Rizzo, V.: Use of differential SAR interferometry in monitoring and modelling large slope instability at Maratea (Basilicata, Italy), Eng. Geol., 6, 31-51, 2003.

Berthier, E., Vadon, H., Baratoux, D., Arnaud, Y., Vincent, C., Feigl, K. L., Rémy, F., and Legrésy, B.: Surface motion of mountain derived from satellite optical imagery, Remote Sens. Environ., 95, 14-28, 2005.

Borghuis, A. M., Chang, K., and Lee, H. Y.: Comparison between automated and manual mapping of typhoon-triggered landslides from SPOT-5 imagery, Int. J. Remote Sens., 28, 1843-1856, 2007

Canuti, P., Casagli, N., Ermini, L., Fanti, R., and Farina, P.: Landslide activity as a geoindicator in Italy: significance and new perspectives from remote sensing, Environ. Geol., 45, 907-919, 2004.

Canuti, P., Casagli, N., Catani, F., Falorni, G., and Farina, P.: Integration of remote sensing techniques in different stages of landslide response, in: Progress in Landslide Sciences, edited by: Sassa, K., Fukuoka, H., Wang, F., and Wang, G., Springer-Verlag, Berlin, 251-259, 2007.

Casagli, N., Fanti, R., Nocentini, M., and Righini, G.: Assessing the capabilities of VHR satellite data for debris flow mapping in the Machu Picchu area, in: Landslides, risk analysis and sustainable disaster management, edited by: Sassa, K., Fukuoka, H., Wang, F., and Wang, G., Proceeding of the First General Assembly of the International Consortium on Landslides, 2005.
Casagli, N., Tofani, V., and Adler, R.: A look from space, in: Landslides, Disaster Risk Reduction, edited by: Sassa, K. and Canuti P., Springer, Berlin, 287-319, 2009.

Cascini, L., Fornaro, G., and Peduto, D.: Analysis at medium scale of low-resolution DInSAR data in slow-moving landslideaffected areas, ISPRS J. Photogram. Remote Sens., 64, 598-611, doi:10.1016/j.isprsjprs.2009.05.003, 2009.

Casson, B., Delacourt, C., and Allemand, P.: Contribution of multitemporal remote sensing images to characterize landslide slip surface - Application to the La Clapière landslide (France), Nat. Hazards Earth Syst. Sci., 5, 425-437, doi:10.5194/nhess-5-4252005, 2005.

Casu, F., Manzo, M., and Lanari, R.: A quantitative assessment of the SBAS algorithm performance for surface deformation retrieval from DInSAR data, Remote Sens. Environ., 102, 195210, 2006.

Catani, F., Casagli, N., Ermini, L., Righini, G., and Menduni, G.: Landslide hazard and risk mapping at catchment scale in the Arno River basin, Landslides, 2, 329-342, doi:10.1007/s10346005-0021-0, 2005.

Cheng, K., Wei, C., and Chang, S.: Locating landslides using multitemporal satellite images, Adv. Space Res., 33, 296-301, 2004.

Colesanti, C. and Wasowski, J.: Investigating landslides with satellite Synthetic Aperture Radar (SAR) interferometry, Eng. Geol., 88, 173-199, 2006.

Colesanti, C., Ferretti, A., Prati, C., and Rocca, F.: Monitoring landslides and tectonic motions with the Permanent Scatterers technique, Eng. Geol., 68, 3-14, 2003.

Crosetto, M., Biescas, E., Duro, J., Closa, J., and Arnaud A.: Generation of advanced ERS and Envisat interferometric SAR products using the stable point network technique, Photogramm. Eng. Remote. Sens., 74, 443-450, 2008.

Cruden, D. M. and Varnes, D. J.: Landslides Types and Processes, in: Landslides: Investigation and Mitigation, edited by: Turner, A. K. and Schuster, R. L., Transportation Research Board Special Report 247, National Academy Press, WA, 36-75, 1996.

Debella-Gilo, M. and Kääb, A.: Sub-pixel precision image matching for measuring surface displacements on mass movements using normalized cross-correlation, Remote Sens. Environ., 115, 130-142, 2011.

Delacourt, C., Alleman, P., Casson, B., and Vadon, H.: Velocity field of the "La Clapiere" landslide measured by the correlation of aerial and QuickBird satellite images, Geophys. Res. Lett., 31, 1561, doi:10.1029/2004GL020193, 2004.

Delacourt, C., Allemand, P., Berthier, E., Raucoules, D., Casson, B., Grandjean, P., Pambrun, C., and Varel, E.: Remote-sensing techniques for analysing landslide kinematics: a review, B. Soc. Geol. Fr., 178, 89-100, 2007.

Delacourt, C., Raucoules, D., Mouélic, S. L., Carnec, C., Feurer, D., Allemand, P., and Cruchet, M.: Observation of a large landslide on la Reunion island using differential SAR interferometry (JERS and Radarsat) and correlation of optical (Spot5 and aerial) images, Sensors, 9, 616-630, 2009.

Dikau, R., Cavallin, A., and Jager, S.: Databases and GIS for landslide research in Europe, Geomorphology, 15, 227-239, 1996.

Fell, R., Corominas, J., Bonnard, C., Cascini, L., Leroi, E., and Savage, W. Z.: Guidelines for landslide susceptibility, hazard and risk zoning for land-use planning, Eng. Geol., 102, 99-111, 2008. 
Ferretti, A., Prati, C., and Rocca, F.: Nonlinear subsidence rate estimation using permanent scatterers in differential SAR interferometry, Geosci. Remote Sens., IEEE Transactions, 38, 22022212, 2000.

Ferretti, A., Prati, C., and Rocca, F.: Permanent Scatterers in SAR Interferometry, IEEE Trans. Geosci. Remote Sens., 39, 8-20, 2001.

Ferretti, A., Fumagalli, A., Novali, F., Prati, C., Rocca, F., and Rucci, A.: A New Algorithm for Processing Interferometric Data-Stacks: SqueeSAR, IEEE T. Geosci. Remote., 49, 34603470, 2011.

Fornaro, G., Pauciullo, A., and Serafino, F.: Deformation Monitoring over large areas with Multipass Differential SAR Interferometry: a new approach based on the use of Spatial Differences, Int. J. Remote Sens., 30, 1455-1478, 2009.

Fruneau, B., Achache, J., and Delacourt, C.: Observation and modelling of the Saint-Etienne-de-Tinee landslide using SAR interferometry, Tectonophysics, 265, 181-190, 1996.

Gibson, A. D., Culshaw, M. G., Dashwood, C., and Pennington, C. V. L.: Landslide management in the UK-the problem of managing hazards in a "low-risk" environment, Landslides, doi:10.1007/s10346-012-0346-4, online first, 2012.

Grebby, S., Naden, J., Cunningham, D., and Tansey, K.: Integrating airbornemultispectral imagery and airborne LiDAR data for enhanced lithological mapping invegetated terrain, Remote Sens. Environ., 115, 214-226, 2011.

Günther, A., Reichenbach, P., Malet, J.-P., Van Den Eeckhaut, M., Hervás J., Dashwood, C., and Guzzetti, F.: Tier-based approaches for landslide susceptibility assessment in Europe, Landslides, doi:10.1007/s10346-012-0349-1, online first, 2012.

Guzzetti, F.: Landslide fatalities and the evaluation of landslide risk in Italy, Eng. Geol., 58, 89-107, 2000.

Guzzetti, F., Stark, C. P., and Salvati, P.: Evaluation of Flood and Landslide Risk to the Population of Italy, Environ. Manage., 36, 15-36, 2005.

Herrera, G., Notti D., Garcia-Davalillo, J. C., Mora, O., Cooksley, G., Sanchez, M., Arnaud, A., and Crosetto, M.: Analysis with C- and X-band satellite SAR data of the Portalet landslide area, Landslides, 8, 195-206, 2011.

Hilley, G. E., Bürgmann, R., Ferretti, A., Novali, F., and Rocca, F.: Dynamics of Slow-Moving Landslides from Permanent Scatterer Analysis, Science, 304, 1952-1955, 2004.

Hong, Y., Adler, R., and Huffman, G.: Evaluation of the Potential of NASA Multi-satellite Precipitation Analysis in Global Landslide Hazard Assessment, Geophys. Res. Lett., 33, L22402, doi:10.1029/2006GL028010, 2006.

Hong, Y., Adler, R., and Huffman, G.: Use of satellite remote sensing data in the mapping of global landslide susceptibility, Nat. Hazards, 43, 23-44, 2007.

Hooper, A., Zebker, H., Segall, P., and Kampes, B.: A new method for measuring deformation on volcanoes and other natural terrains using InSAR persistent scatterers, Geophys. Res. Lett., 31, doi:10.1029/2004GL021737, 2004.

Hooper, A., Segall, P., and Zebker, H.: Persistent scatterer interferometric synthetic aperture radar for crustal deformation analysis, with application to Volcan Alcedo, Galapagos, J. Geophys. Res.Sol. Earth, 112, B07407, doi:10.1029/2006JB004763, 2007.

Kääb, A.: Monitoring high-mountain terrain deformation from repeated air- and spaceborne optical data: examples using digital aerial imagery and ASTER data, J. Photogramm. Remote Sens., 57, 39-52, 2002.

Kimura, H. and Yamaguchi, Y.: Detection of landslide areas using radar interferometry, Photogram. Eng. Remote Sens., 66, 337344, 2000.

Kirschbaum, D. B., Adler, R., Hong, Y., and Lerner-Lam, A.: Evaluation of a preliminary satellite-based landslide hazard algorithm using global landslide inventories, Nat. Hazards Earth Syst. Sci., 9, 673-686, doi:10.5194/nhess-9-673-2009, 2009.

Lanari, R., Mora, O., Manunta, M., Mallorqui, J. J., Berardino, P., and Sansosti, E.: A small-baseline approach for investigating deformations on full-resolution differential SAR interferograms, Trans. Geosci. Remote Sens., 42, 1377-1386, 2004.

Leprince, S., Barbot, F., Ayoub, J., and Avouac, J.-P.: Automatic and precise ortho-rectification, coregistration, and subpixel correlation of satellite images. Application to ground deformation measurements, IEEE Trans. Geosci. Remote Sens., 45, 1529-1558, 2007.

Leprince, S., Berthier, E., Ayoub, F., Delacourt, C., and Avouac, J.P.: Monitoring Earth Surface Dynamics With Optical Imagery, Eos, 89, 1-5, 2008.

Lu, P., Stumpf, A., Kerle, N., and Casagli, N.: Object-oriented change detection for landslide rapid mapping, Geosci. Remote Sens. Lett., 8, 701-705, 2011.

Lu, P., Casagli, N., Catani, F., and Tofani, V.: Persistent Scatterers Interferometry Hotspot and Cluster Analysis (PSI-HCA) for detection of extremely slow-moving landslides, Int. J. Remote Sens., 33, 466-489, 2012.

Luzi, G., Monserrat, O., Crosetto, M., Copons, R., and Altimir, J.: "Ground-Based SAR Interferometry applied to landslide monitoring in mountainous areas", Mountain Risks conference: Bringing Science to Society, Firenze (IT), 24-26, 2010.

Mantovani, F., Soeters, R., and Van Westen, C. J.: Remote sensing techniques for landslide studies and hazard zonation in Europe, Geomorphology, 15, 213-225, 1996.

Marcelino, E. V., Formaggio, A. R., and Maed, E. E.: Landslide inventory using image fusion techniques in Brazil, Int. J. Appl. Earth Obs. Geoinf., 11, 181-191, 2009.

Martha, T., Kerle, N., van Westen, C. J., and Kumar, K.: Characterising spectral, spatial and morphometric properties of landslides for semi-automatic detection using object-oriented methods, Geomorphology, 116, 24-36, 2010.

Massonnet, D. and Feigl, K. L.: Radar interferometry and its application to changes in the earth's surface, Rev. Geophys., 36, 441-500, 1998.

Meisina, C., Zucca, F., Conconi, F., Verri, F., Fossati, D., Ceriani, M., and Allievi, J.: Use of Permanent Scatterers technique for large-scale mass movement investigation, Quaternary Int., 171172, 90-107, 2007.

Mora, P., Baldi, P., Casula, G., Fabris, M., Ghirotti, M., Mazzini, E., and Pesci, A.: Global Positioning Systems and digital photogrammetry for the monitoring of mass movements: application to the $\mathrm{Ca}$ ' di Malta landslide (northern Apennines, Italy), Eng. Geol., 68, 103-121, 2003.

Nichol, J. and Wong, M. S.: Satellite remote-sensing for detailed landslide inventories using change detection and image fusion, Int. J. Remote Sens., 26, 1913-1926, 2005.

Noferini, L., Pieraccini, M., Mecatti, D., Luzi, G., Tamburini, A., Broccolato, M., and Atzeni, C.: Permanent scatterers analysis 
for atmospheric correction in Ground Based SAR Interferometry, Trans. Geosci. Remote Sens., 43, 1459-1471, 2005.

Pancioli, V., Raetzo, H., Campolmi, T., and Casagli, N.: Terrafirma Landslide Services for Europe based on Space-borne InSAR Data, in: Proceedings of the First World Landslide Forum, Tokyo, Japan, 81-84, 2008.

Petley, D.: Global patterns of loss of life from landslidesm Geology, 40, 927-930, 2012

Petley, D. N., Dunning, S. A., and Rosser N. J.: The analysis of global landslide risk through the creation of a database of worldwide landslide fatalities, in: Landslide Risk Management, edited by: Hungr, O., Fell, R., Couture, R., and Eberhardt, E., Taylor \& Francis Group, London, ISBN 041538043 X, 2005.

Peyret, M., Djamour, Y., Rizza, M., Ritz, J. F., Hurtrez, J. E., Goudarzi, M. A., Nankali, H., Chèry, J., Le Dortz, K., and Uri, F.: Monitoring of a large slow Kahrod landslide in Alborz mounatin range (Iran) by GPS and SAR interferometry, Eng. Geol., 100, 131-141, 2008

Prati, C., Ferretti, A., and Perissin, D.: Recent advances on surface ground deformation measurement by means of repeated spaceborne SAR observations, J Geodynam., 49, 161-170, 2010.

Righini, G., Pancioli, V., and Casagli, N.: Updating landslide inventory maps using Persistent Scatterer Interferometry (PSI), Int. J. Remote Sens., 33, 2068-2096, 2012.

Rizzo, V. and Tesauro, M.: SAR interferometry and field data of Randazzo landslide (Eastern Sicily, Italy), Phys. Chem. Earth B, 25, 771-780, 2000.

Rossi, G., Catani, F., Leoni, L., Segoni, S., and Tofani, V.: HIRESSS: a physically based slope stability simulator for HPC applications, Nat. Hazards Earth Syst. Sci., 13, 151-166, doi:10.5194/nhess-13-151-2013, 2013.

Rott, H. and Siegel, A.: Analysis of mass movements in alpine terrain $b$, means of SAR interferometry, Geoscience and Remote Sensing Symposium, 1999. IGARSS '99 Proceedings. IEEE 1999 International, 1933-1936, doi:10.1109/IGARSS.1999.774991, 1999.

Sarkar, S. and Kanungo, D. P.: An Integrated Approach for Landslide Susceptibility Mapping using Remote-sensing and GIS, Photogram. Eng. Remote Sens., 70, 617-625, 2004.

Schuster, R. L.: Socioeconomic significance of landslides, in: Landslides: Investigation and Mitigation. Transportation Research Board, edited by: Turner, A. K. and Schuster, R. L., Special Report 247, National Academy Press, WA (1995), 12-35, 1996.

Schuster, R. L. and Highland, L. M.: Socioeconomic and Environmental Impacts of Landslides in the Western Hemisphere: US Geological Survey Open-File Report 01-0276, 47 pp., available at: http://pubs.usgs.gov/of/2001/ofr-01-0276/, 2001.

Segoni, S., Leoni, L., Benedetti, A. I., Catani, F., Righini, G., Falorni, G., Gabellani, S., Rudari, R., Silvestro, F., and Rebora, N.: Towards a definition of a real-time forecasting network for rainfall induced shallow landslides, Nat. Hazards Earth Syst. Sci., 9, 2119-2133, doi:10.5194/nhess-9-2119-2009, 2009.

Singhroy, V.: SAR integrated techniques for geohazard assessment, Adv. Space Res., 15, 67-78, 1995.

Singhroy, V. and Molch, K.: Characterizing and monitoring rockslides from SAR techniques, Adv. Space Res., 33, 290-295, 2004.

Soeters, R. and Van Westen, C.: Slope instability recognition, analysis and zonation, in: Landslides, investigation and mitigation, edited by: Turner, A. K. and Schuster, R. L., Transportation Research Board, National Research Council, National Academy Press, Washington, USA, 129-177, 1996.

Strozzi, T., Farina, P., Corsini, A., Ambrosi, C., Turing, M., Zilger, J., Wiesmann, A., Wegmuller, U., and Werner, C.: Survey and monitoring of landslide displacements by means of L-band satellite SAR interferometry, Landslides, 2, 193-201, doi:10.1007/s10346-005-0003-2, 2005.

Strozzi, T., Wegmuller, U., Keusen, H. R., Graf, K., and Wiesmann, A.: Analysis of the terrain displacement along a funicular by SAR interferometry, Trans. Geosci. Remote Sens., 3, 15-18, 2006.

Strozzi, T., Delaloye, R., Kääb, A., Ambrosi, C., Perruchoud, E., and Wegmüller, U.: Combined observations of rock mass movements using satellite SAR interferometry, differential GPS, airborne digital photogrammetry, and airborne photography interpretation, J. Geophys. Res., 115, F01014, doi:10.1029/2009JF001311, 2010.

Stumpf, A. and Kerle, N.: Object-oriented mapping of landslides using Random Forests, Remote Sens. Environment., 115, 2564 2577, 2011.

Stumpf, A., Kerle, N., Malet, J.-P., and other SafeLand partners: Guidelines for the selection of appropriate remote sensing technologies for monitoring different types of landslides. Deliverable D4.4 of SafeLand Project, 91 pp., available at: http://www. safeland-fp7.eu, 2012.

Sturzenegger, M. and Stead, D.: Quantifying discontinuity orientation and persistence on high mountain rock slopes and large landslides using terrestrial remote sensing techniques, Natural Hazards and Earth System Sciences, 9, 267-287, 2009.

Tofani, V., Catani, F., Pancioli, V., Moretti, S., and Casagli, N.: Integration of PSI technique and conventional ground-based methods for characterization and monitoring of Santo Stefano d'Aveto landslide (Central Italy), in: Mountain Risks: bringing Science to Society, edited by: Malet, J. P., Glade, T., and Casagli, N., Cerg Editions, Strasbourg, 301-330, 2010.

Tofani, V., Segoni, S., Casagli, N., Catani, F., and other SafeLand partners: Evaluation report on innovative monitoring and remote sensing methods and future technology, Deliverable 4.5 of Safeland project, 280 pp., available at: http://www.safeland-fp7.eu., 2011.

Travelletti, J., Delacourt, C., Allemand, P., Malet, J.-P., Schmittbuhl, J., Toussaint, R., andBastard, M.: Correlation of multitemporal ground-based optical images for landslide monitoring: Application, potential and limitations, J. Photogram. Remote Sens., 70, 39-55, 2012

Trigila, A., Iadanza, C., and Spizzichino, D.: Quality assessment of the Italian Landslide Inventory using GIS processing, Landslides, 7, 455-470, 2010.

Tsai, F., Hwang, J.-H., Chen, L.-C., and Lin, T.-H.: Post-disaster assessment of landslides in southern Taiwan after 2009 Typhoon Morakot using remote sensing and spatial analysis, Nat. Hazards Earth Syst. Sci., 10, 2179-2190, doi:10.5194/nhess-10-21792010, 2010.

Van Den Eeckhaut, M. and Hervás, J.: State of the art of national landslide databases in Europe and their potential for assessing landslide susceptibility, hazard and risk, Geomorphology, 139140, 545-558, 2012. 
Van Den Eeckhaut, M., Hervás, J., Jaedicke, C., Malet, J.-P., Montanarella, L., and Nadim, F.: Statistical modelling of Europe-wide landslide susceptibility using limited landslide inventory data, Landslides, 9, 357-369, 2012.

Van Puymbroeck, N., Michel, R., Binet, R., Avouac, J-P., and Taboury, J.: Measuring Earthquakes from Optical Satellite Images, Appl. Opt., 39, 3486-3494, 2000.

van Westen, C. J., Castellanos, E., and Kuriakose, S. L.: Spatial data for landslide susceptibility, hazard, and vulnerability assessment: An overview, Eng. Geol., 102, 112-131, 2008.

Wasowski, J., Casarano, D., Lamanna, C., Bovenga, F., Conte, D., Nutricato, R., Berardino, P., Manzo, M., Pepe, A., Zeni, G., Lanari, R., and Refice A.: A comparative analysis of DInSAR results achieved by the SBAS and SPINUA techniques: the Maratea valley case study, Italy. Proc. Envisat Symposium 2007, Montreux, Switzerland 23-27 April 2007 (ESA SP-636, July 2007), 2007.
Weirich, F. and Blesius, L.: Comparison of satellite and air photo based landslide susceptibility maps, Geomorphology, 87, 352364, 2007.

Werner, C., Wegmuller, U., Strozzi, T., andWiesmann, A.: Interferometric point target analysis for deformation mapping, in: IGARSS 2003, Toulouse, France, 21-25 July 2003, Piscataway, NJ, 4362-4364, 2003. 